\title{
A STUDY ON AN EFFECT OF THE GREEN TEA EXTRACT ON QUALITY AND SHELF LIFE OF ANIMAL FATS DURING STORAGE
}

\author{
Konstantin A. Lehukov, Sergei S. Tsikin* \\ Orel State agrarian University named after N. V. Parahin, Orel, Russia
}

Key words: antioxidants, fat storage, fat oxidation

\begin{abstract}
An analysis of an effect of the green tea extract on quality and shelf life of animal fats is presented. It is shown that the rate and depth of fat hydrolysis depend on a storage temperature. The higher the storage temperature, the higher the rate of fat hydrolysis and, consequently, the acid value. During storage for more than 3 days at any temperature, fats (except mutton fat) begin to change their properties. Mutton fat shows the first signs of spoilage (an increase in the acid value of more than $2.2 \mathrm{mg} K O H, M A C ~ N D)$ after 10 days of storage. An insignificant variation in the peroxide value of all tested fats during 10 days of storage, which was within the range of MAC, was established. After 10 days of storage, the rate of formation of peroxides and hydroperoxides rose sharply, which was confirmed by the peroxide value of these fats. Addition of antioxidants of the green tea extract in an amount of $10 \mathrm{~g}$ per $100 \mathrm{~kg}$ fat ensured appropriate storage of all fat types upon storage conditions that corresponded to the normative and technical documentation.
\end{abstract}

\section{Introduction}

According to the state policy of the Russian Federation in the field of healthy nutrition of the population for the period of up to 2020, the most important task is the development of production of foods that facilitate maintenance and strengthening of health of different population groups [1].

The unfavorable ecological situation and nutrition provoke oxidative processes in the human body, which cause cell dysfunction and an increase in cardiovascular, oncological and other chronic diseases. To improve population health, it is necessary to manufacture products, which composition includes natural ingredients with antioxidant properties $[2,3]$.

The topicality of this problem is determined by fluctuations on the market: an increase or decrease in consumer demand, a necessity to transport products over large distances, weather conditions are the main factors that require taking appropriate measures that would guarantee high commercial quality of melted fats.

The production technology for animal fats based on melting includes their dehydration. Therefore, they contain in the final form not more than $0.2-0.3 \%$ of moisture, which facilitates an increase in their storage stability. At the same time, edible fats are prone to changes (rancidification and tallowiness) under unsatisfactory storage conditions $[3,4]$.

Recently, a trend towards a pronounced growth in the use of certain fats for improving foods, consumer properties and the nutritional value is observed. It is this direction that is most promising for the development of the Russian market of animal fats.

It is known that most unstable during storage is pork fat, which upon the contact with air oxygen and under an effect of light is subjected to oxidative changes. As a result of chain destructive reactions, oxidation products (hydroperoxides, aldehydes and ketones, dibasic fatty acids) accumulate in fat. A consequence of this are unpleasant odor and taste, as well as color changes $[5,6]$.

The use of inhibitors of oxidative spoilage allows retardation of these negative processes and, thereby, prevention of product spoilage. The main requirements for their use are safety, availability, low cost, simplicity of using, absence of odor and taste, inhibition effectiveness. Inhibitors from natural raw materials are preferable. We propose to use bioflavonoids with the antioxidant properties in the production process as an alternative $[7,8]$.

The aim of the research was to study an effect of antioxidants of the green tea extract on physico-chemical characteristics of animal fats during storage.

\section{Materials and methods}

The objects of the research were pork, beef, mutton and goose fats.

Measurement of moisture content

The method is based on drying a fat specimen to a constant weight.

Work procedure. Fat (2-3 g) is put into an empty weighing container preliminarily dried to a constant weight, weighed with an accuracy of 0.0002 , placed into a drying oven and dried at a temperature of $100-105^{\circ} \mathrm{C}$. The first weighing is carried out after 1 hour of drying, the following ones after 30 min. of drying. The weighing container is cooled in a desiccator for 20-25 min.

The moisture content $X(\%)$ is calculated by the equation:

where

$$
X=\frac{\left(M_{1}-M_{2}\right)}{M_{0}} \cdot 100,
$$

$M_{1}$ is the weight of the weighing container with fat before drying, g; 
$M_{2}$ is the weight of the weighing container with fat after dry-

ing, $\mathrm{g}$;

$M_{0}$ is the fat weight, $\mathrm{g}$.

\section{Methodical note}

Considering that fat oxidation is possible, the lowest weight is taken into account in drying.

Determination of the acid value

The acid value characterizes the depth of hydrolytic decomposition of fats and is an indicator of oxidative spoilage in investigation of stored melted fat along with other more characteristic indices. Cleavage of triglycerides of fatty tissue takes place under the action of lipases catalyzing hydrolysis of ester bonds. The reactions of hydrolytic cleavage are accelerated with an increase in a temperature in the presence of bases, acids. Hydrolysis of fat and the corresponding increase in the acid value can occur at the beginning of the technological process mainly by the enzymatic way and then non-enzymatic hydrolysis of triglycerides is possible at the stage of melting after lipase inactivation $[9,10]$.

\section{Principle of the method}

Titration of free fatty acids in the ether/ethanol solution of fat with the alkaline aqueous solution.

Ether serves as a fat solvent and ethanol is used for homogenization of the system formed by the alkaline aqueous solution and fat during titration.

Work procedure

Fat (3-5 g) is weighed in a $250 \mathrm{ml}$ conical flask with an accuracy of $0.01 \mathrm{~g}$. Fat is melted in a water bath and $30-50 \mathrm{ml}$ of the neutralized mixture of ethanol and diethyl ether are added. The content of the flask is agitated. Two or three drops of the indicator ( $1 \%$ phenolphthalein solution) are added to the solution and quick titration is carried out until appearance of the pink color.

The acid value is calculated by the equation:

$$
X=\frac{5,61 \cdot V \cdot K}{M},
$$

where

5.61 is the titer of $0.1 \mathrm{~N}$ potassium hydroxide solution, $\mathrm{mg} / \mathrm{ml}$;

$K$ is the adjustment coefficient to the alkaline solution;

$V$ is the amount of $0.1 \mathrm{~N}$ potassium hydroxide solution used for titration, $\mathrm{ml}$;

$M$ is the fat weight, $\mathrm{g}$.

\section{Methodical notes}

In case of fluid turbidity in the flask, 5-10 $\mathrm{ml}$ of ether/ ethanol mixture are added. If turbidity does not disappear, the flask is slightly heated in a water bath and titration is carried out after cooling.

The neutral ether/ethanol mixture is prepared by mixing one part of $96 \%$ ethanol with two parts of diethyl ether, the indicator (phenolphthalein solution $1 \%$ in ethanol) is added; after that, it is neutralized with $0.1 \mathrm{~N}$ alkaline solution to the slightly pink color.

\section{Determination of the peroxide value}

The peroxide value characterizes a degree of fat oxidative spoilage. At the first stages of oxidation of fatty acid esters, hydroperoxides are formed. As a result of decomposition or other transformations of peroxides, intermediate and end products of oxidation emerge: alcohols, aldehydes, ketones, low molecular weight acids, oxyacids and others, many of which take part in appearance of odor and taste of spoiled fat. The oxidation rate is influenced by the nature of fatty acids, presence of catalyzers, natural antioxidants, temperature and light. The oxidation reaction is accelerated by heme pigments.

The delay in raw material processing, high temperature, presence of atmospheric oxygen, contact with metallic equipment, effect of light, inadequate storage conditions stimulate peroxide formation.

The peroxide value is expressed as the number of grams of iodine liberated from potassium iodide in the acidic conditions under an effect of peroxides contained in $100 \mathrm{~g}$ of fat (\% of iodine) [11,12].

There is a certain dependence between the peroxide value and organoleptic indices of fat as substances that change fat taste and odor appear in parallel with accumulation of peroxides (Table 1). A degree of fat freshness is determined depending on the peroxide value.

Table 1. Dependence of fat freshness on the peroxide value

\begin{tabular}{|c|c|}
\hline Fat condition & Peroxide value $(\%$ of iodine) \\
\hline Fresh & Up to 0.03 \\
\hline Fresh, but not storable & 0.03 to 0.05 \\
\hline Doubtful freshness & 0.06 to 0.1 \\
\hline Spoiled & More than 0.1 \\
\hline
\end{tabular}

\section{Principle of the method}

Oxidation of hydroiodic acid with peroxides contained in fat with the following titration of liberated iodine with sodium thiosulphate.

Work procedure

A specimen of fat (about $1 \mathrm{~g}$ ) is weighed in a stoppered conical flask with an accuracy of $0.0002 \mathrm{~g}$. Fat is melted in a water bath. Ten milliliters of chloroform is poured into the flask (along the wall, washing fat particles) from a cylinder; after that, $10 \mathrm{ml}$ of glacial acetic acid and, then, $1 \mathrm{ml}$ of the freshly prepared saturated solution of potassium iodide are added.

The flask is closed with a stopper, the flask content is thoroughly mixed and held in a dark place for $5 \mathrm{~min}$. Then, $100 \mathrm{ml}$ of distilled water and $1 \mathrm{ml}$ of $1 \%$ starch solution are added to the flask and liberated iodine is titrated with 0.01 $\mathrm{N}$ solution of sodium thiosulphate until disappearance of the blue color.

The control test (without fat) is carried out in parallel.

The peroxide value of fat $X$ (\% of iodine) is calculated by the equation:

$$
X=\frac{0,00127 \cdot K \cdot\left(V-V_{1}\right) \cdot 100}{M_{0}},
$$


where

0.00127 is the amount of iodine that is equivalent to $1 \mathrm{ml}$ of the $0.01 \mathrm{~N}$ solution of sodium thiosulphate, $\mathrm{g}$;

$K$ is the adjustment coefficient to the titer of $0.01 \mathrm{~N}$ solution of sodium thiosulphate;

$V$ is the amount of $0.01 \mathrm{~N}$ solution of sodium thiosulphate used for titration of the test solution, $\mathrm{ml}$;

$V_{1}$ is the amount of $0.01 \mathrm{~N}$ solution of sodium thiosulphate used for titration of the control solution, $\mathrm{ml}$;

$M$ is the fat weight, $g$.

\section{Results and discussion}

Various transformations occur under the influence of biological or physico-chemical factors during processing and storage of fatty tissue from slaughter animals or fats extracted from it. The contact of meat fatty tissue with air oxygen, water, microorganisms, metals causes physicochemical and biological processes that change properties of fatty raw materials and meat tissues. The intensity of changes depends both on raw material properties and storage conditions [13]. Oxidative and hydrolytic processes can cause fat spoilage (Figure 1).

As a result, the fat chemical composition changes, the organoleptic indices and nutritional value decline. The processes of hydrolysis and oxidation often occur simultaneously enhancing changes in fat.

A degree of fat spoilage is analyzed not only by the organoleptic, but also by different chemical methods. The results of analyses are usually characterized by arbitrary units - the acid value, peroxide value and other values (GOST R51487-99). Hydrolytic spoilage of fats is characterized by accumulation of free fatty acids. This can be a consequence of autolysis and a result of the action of other factors: acids, alkali, metal oxides and other inorganic catalyzers, as well as microbial enzymes [14].

The hydrolytic decomposition of triglycerides under the action of tissue lipases is observed; as a result, accumulation of free fatty acids expressed in an increase in the acid value of fat is noticed, which is undesirable for fat quality characteristics. The acid value is low and not higher than $0.05-0.2$ in fresh fatty tissue just taken from a carcass.

The rate and depth of fat hydrolysis depend on a storage temperature (Figure 2, Figure 3, Figure 4, Figure 5, Figure 6). The higher a storage temperature, the higher a rate of fat hydrolysis and, consequently, the acid value.

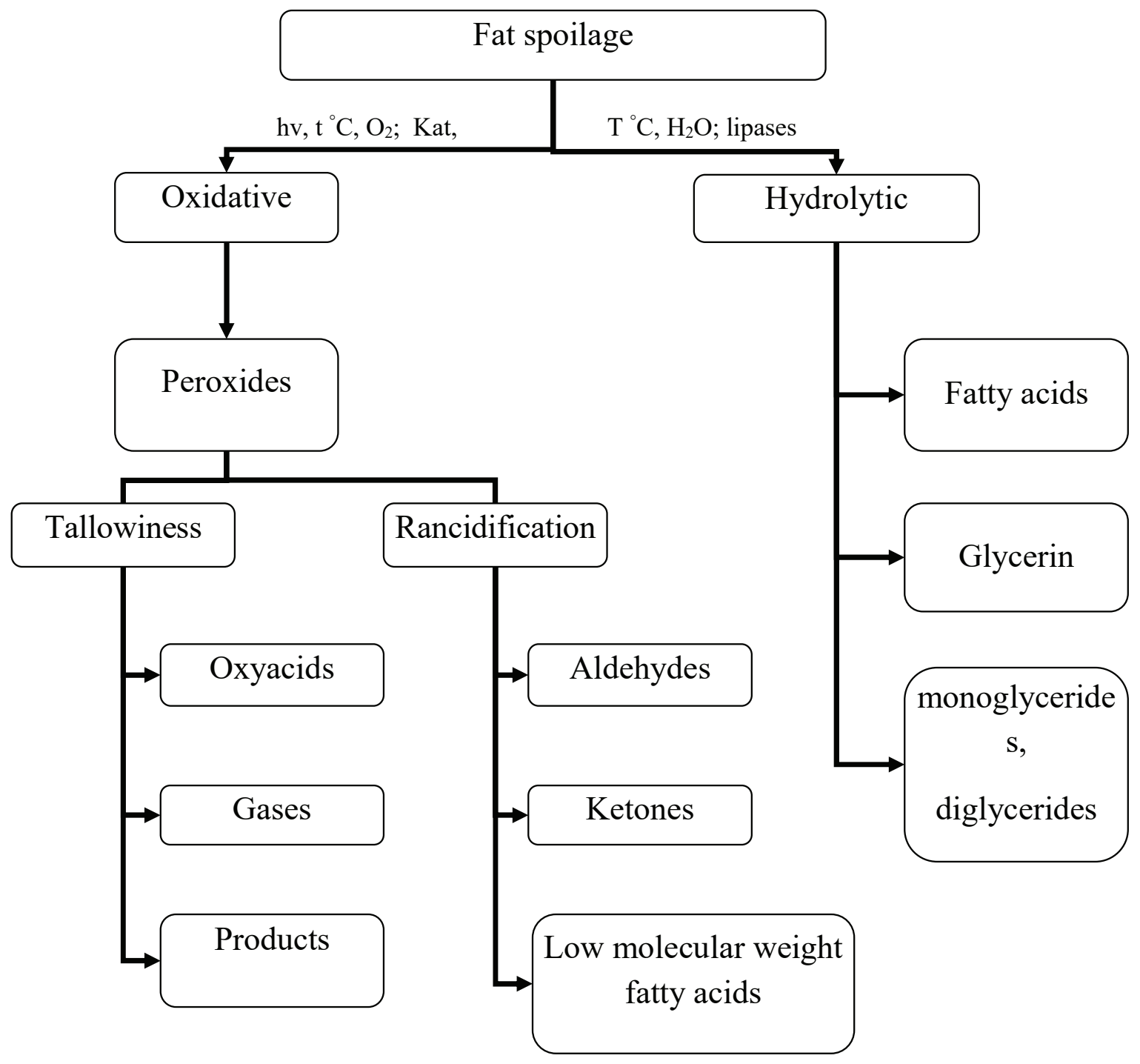

Figure 1. The scheme of fat spoilage 


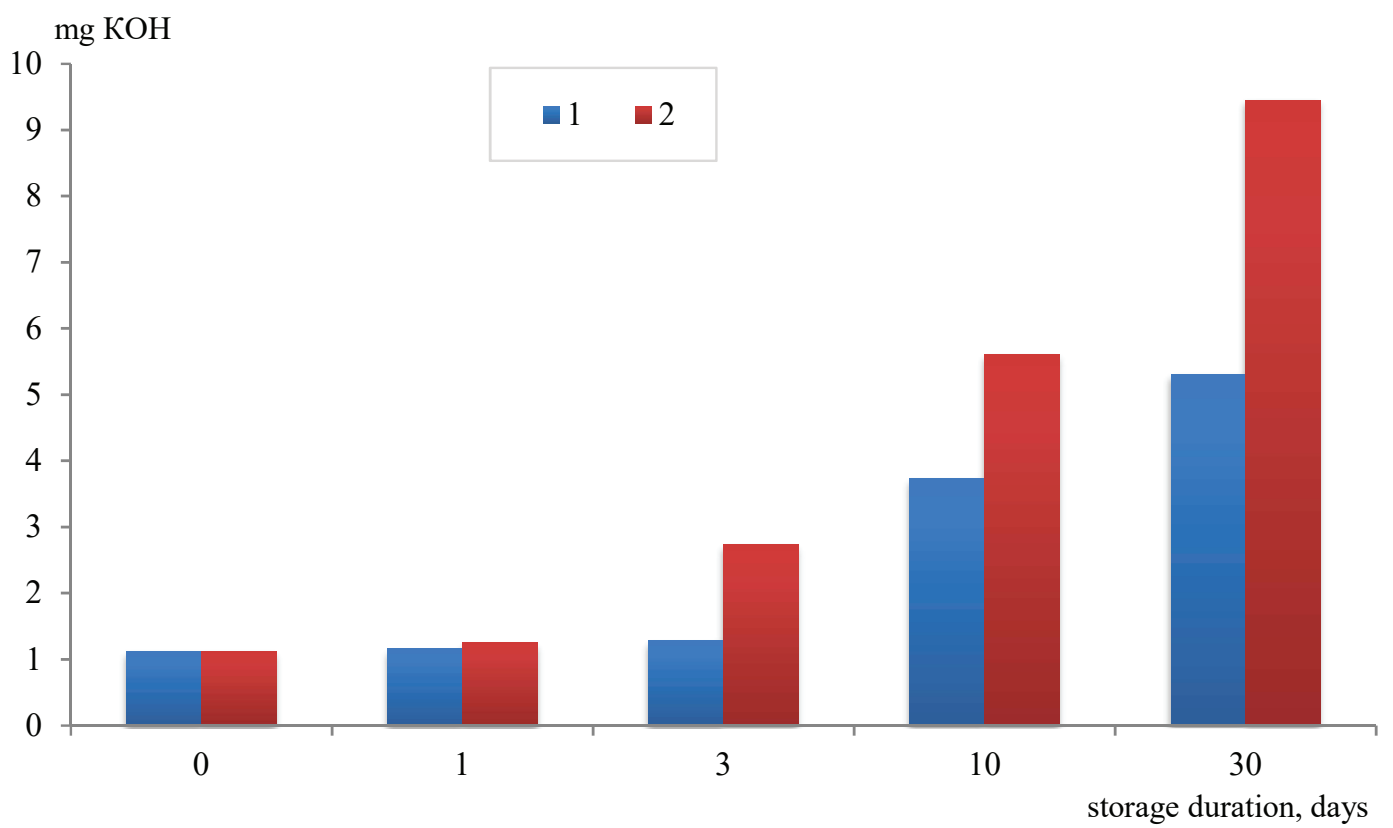

Figure 2. Changes in the acid value of pork backfat during storage at a temperature: 1 at $4{ }^{\circ} \mathrm{C} ; 2$ at $20^{\circ} \mathrm{C}$

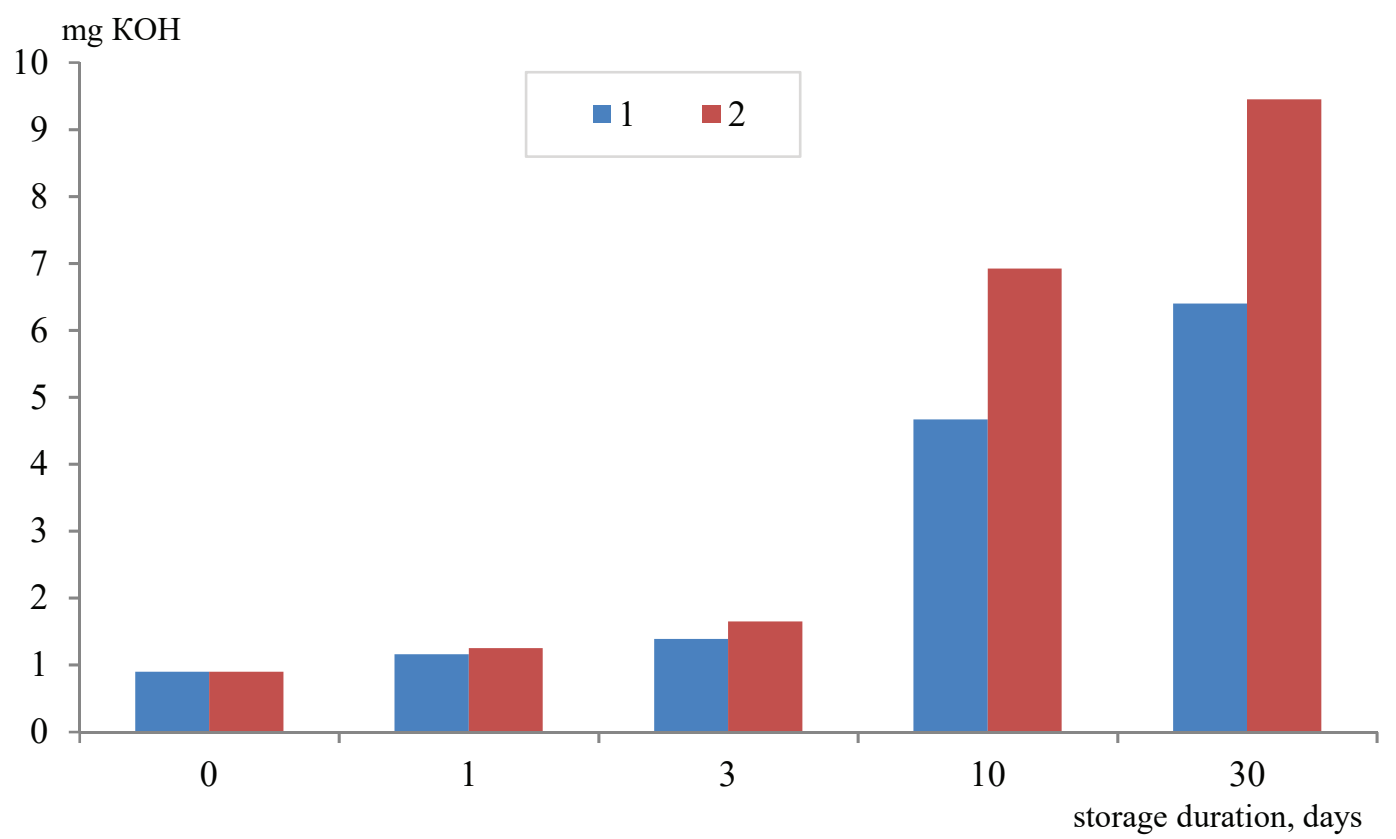

Figure 3. Changes in the acid value of pork fat from flank during storage at a temperature: 1 at $4{ }^{\circ} \mathrm{C} ; 2$ at $20^{\circ} \mathrm{C}$

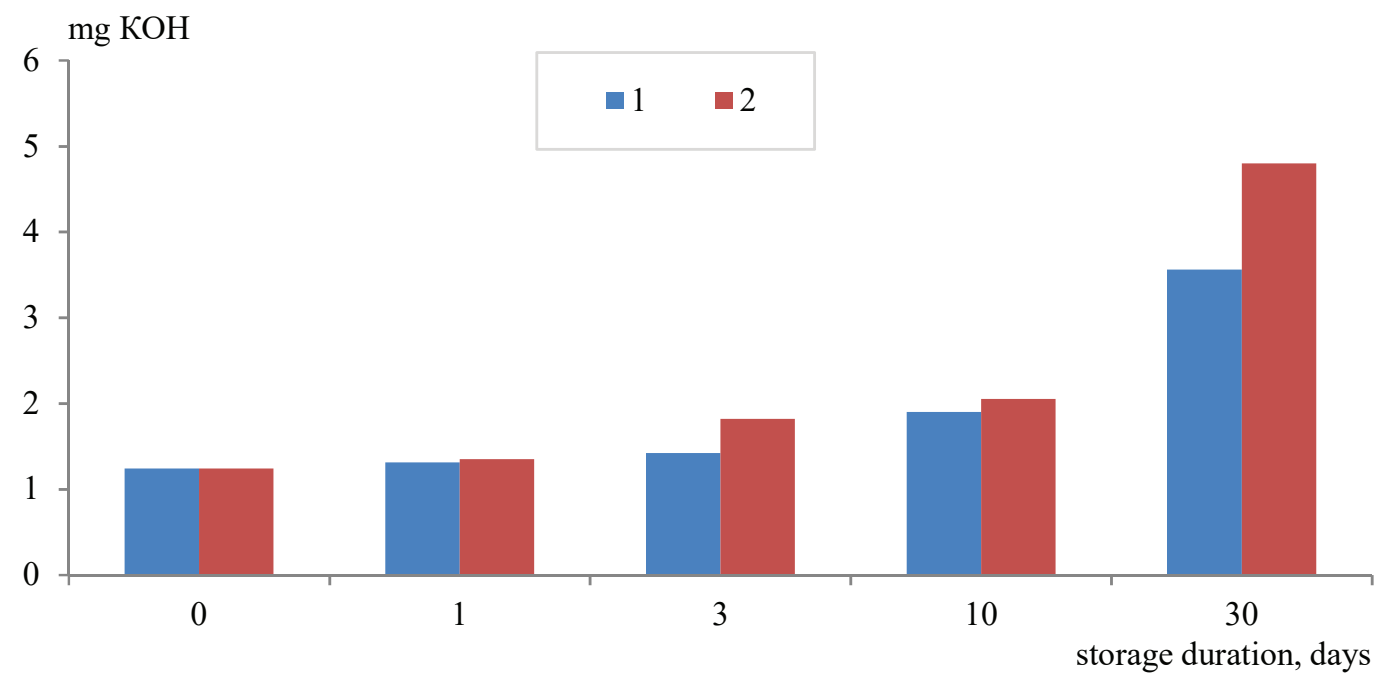

Figure 4. Changes in the acid value of mutton fat during storage at a temperature: 1 at $4{ }^{\circ} \mathrm{C} ; 2$ at $20^{\circ} \mathrm{C}$ 


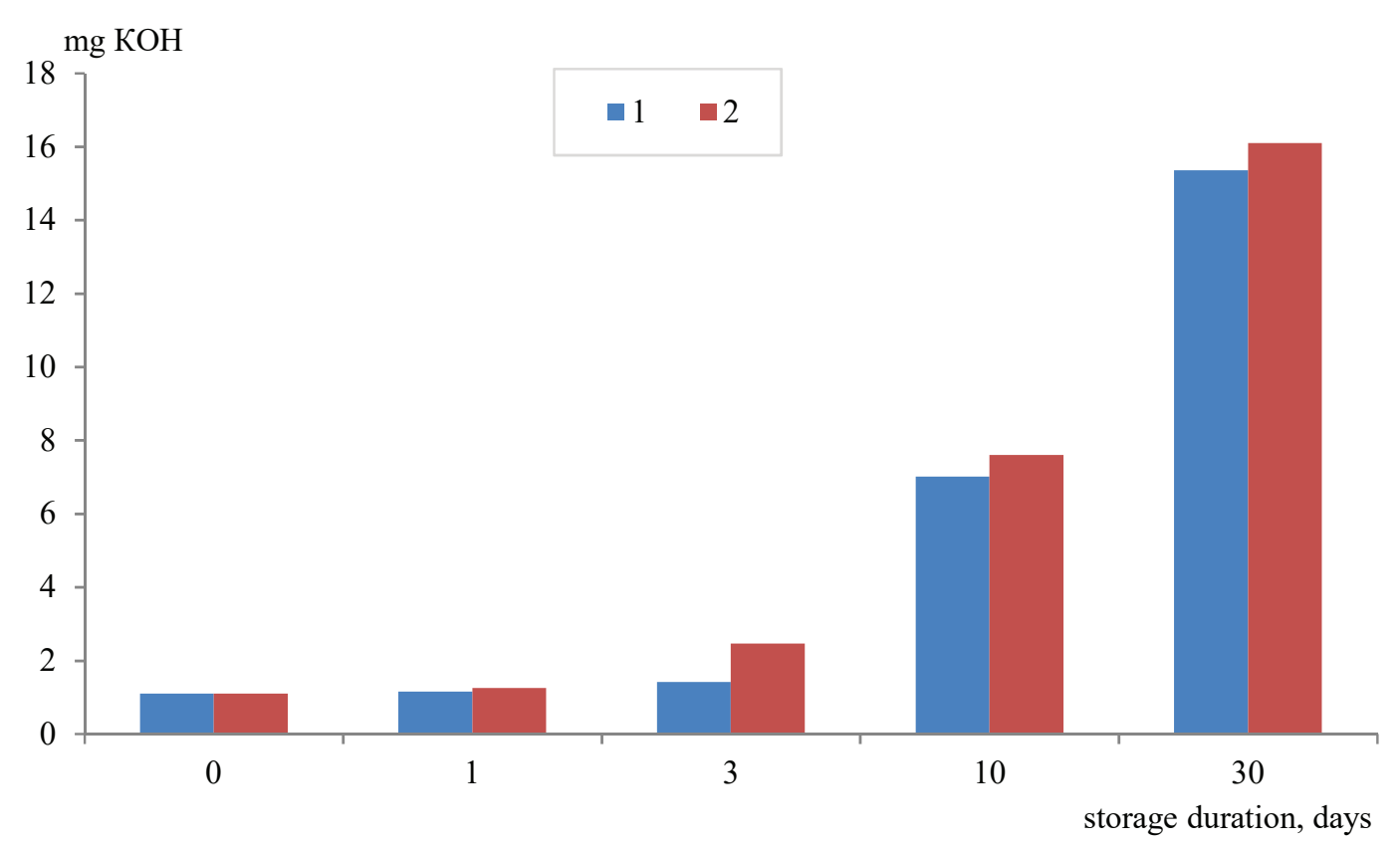

Figure 5. Changes in the acid value of goose fat during storage at a temperature: 1 at $4{ }^{\circ} \mathrm{C} ; 2$ at $20{ }^{\circ} \mathrm{C}$

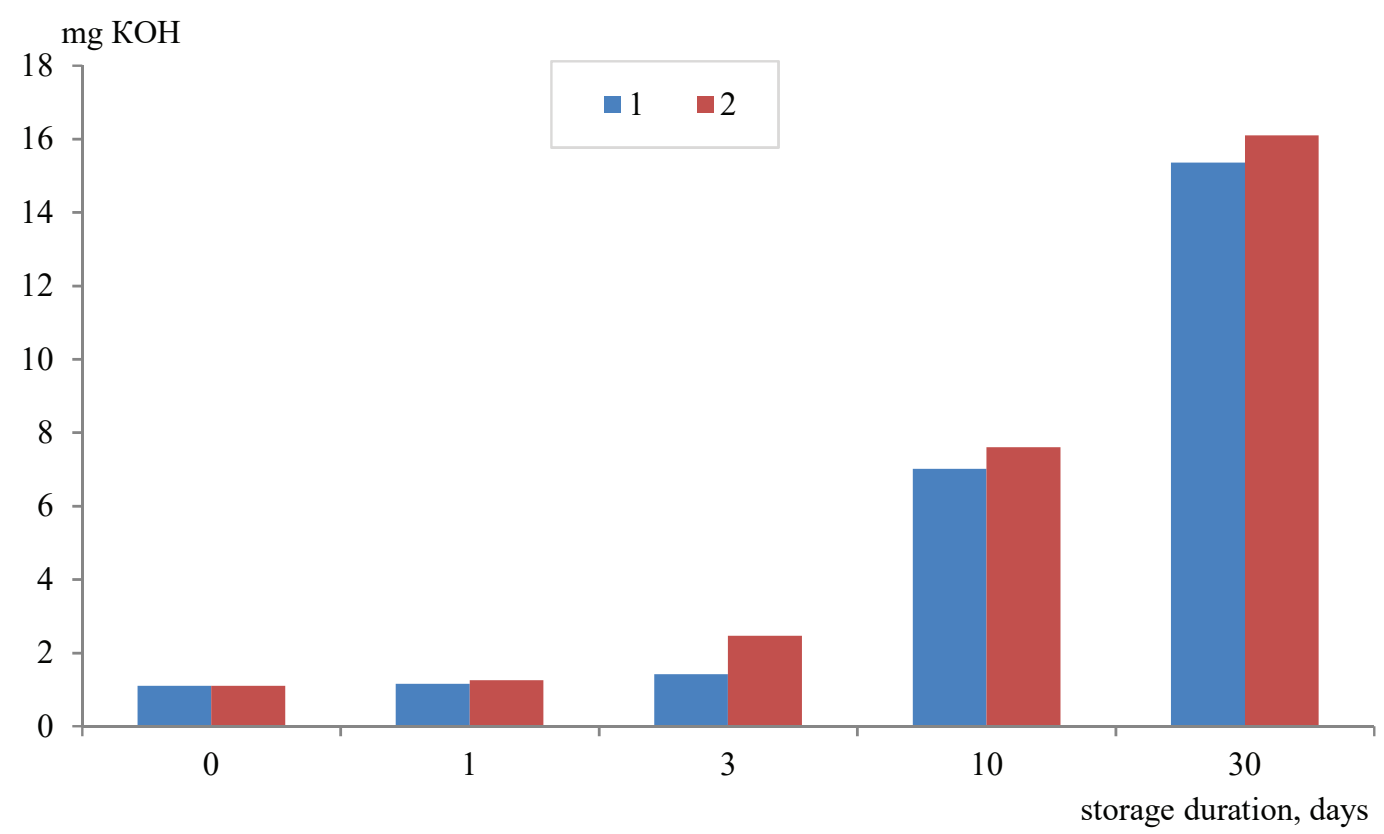

Figure 6. Changes in the acid value of beef fat during storage at a temperature: 1 at $4{ }^{\circ} \mathrm{C} ; 2$ at $20^{\circ} \mathrm{C}$

The results of the investigations showed that a temperature had a different effect on transformations of different types of fat. For example, changes in the acid value of goose and mutton fat during one month at a storage temperature of $4{ }^{\circ} \mathrm{C}$ and $20^{\circ} \mathrm{C}$ differed only by $5 \%$. Therefore, these types of fat can be recommended for the use and storage in warm regions of the country.

Pork backfat and beef fat showed strong dependence on a temperature during storage. Maximum difference was $15 \%$, which suggests a strict adherence to the temperature regimes during storage. Pork fat from flank began to spoil from the third day of storage at a temperature of $20^{\circ} \mathrm{C}$ with increased difference in the acid value of up to $30 \%$ by one month of storage. Thus, it is not recommended to use this type of fat for production of melted fats without using inhibitors [15].
Analysis of data showed that upon storage for more than 3 days at any temperature, fats (except mutton fat) began to change their properties. Mutton fat showed the first signs of spoilage (an increase in the acid value of more than 2.2. $\mathrm{mg} \mathrm{KOH}, \mathrm{MAC} \mathrm{ND}$ ) after ten days of storage.

Appearance of a small amount of high molecular weight fatty acids in fat upon hydrolytic decomposition do not cause changes in product taste and odor. In the presence of low molecular weight acids in the composition of triglycerides, hexanoic acid and butyric acid having unpleasant odor and specific taste, which sharply deteriorate organoleptic properties of a product, can be formed upon hydrolysis [16,17].

As a rule, the autolytic cleavage of fat is not observed in melted fats. This is explained by inactivation of lipase contained in fatty tissue, when a temperature reaches $60^{\circ} \mathrm{C}$ 
during melting. Hydrolytic spoilage of melted fat is possible in the presence of moisture, microbial contamination, incomplete protein denaturation upon melting fat or in the presence of inorganic catalyzers [18].

During storage and processing of fats, their oxidative changes are possible, which can occur with different rates and depths, have different directions depending on natural fat properties and oxidation conditions $[10,13]$.

Oxidation of fats (autooxidation) takes place at low temperatures in the presence of gaseous oxygen.

The beginning and depth of fat oxidation are judged by the peroxide value.

There are no peroxides in fresh fat. At the initial stages of oxidation, chemical and organoleptic indices of fat almost do not change for some time. This period, which has different duration in various fats, is called an induction period. After the end of the induction period, the spoilage of fat begins, which is accompanied with an increase in the peroxide value and changes in fat organoleptic properties.

Occurrence of the induction period is explained by a low number of particles with increased kinetic energy (excited or free radicals) at the beginning of the process $[8,12]$.

The use of antioxidants gives an opportunity to extend the shelf life of food raw materials, semi-products and finished products, protecting them from spoilage caused by oxidation with air oxygen.

Fat oxidation is a complex process, which proceeds by the radical chain mechanism. The duration of the induction period, during which fat spoilage is not observed, depends on the mass fraction of natural (carotenoids, tocopherols, lecithin, vitamins $\mathrm{A}$ and $\mathrm{K}$ ) or artificial (phenol derivatives contained in smoke fume, several natural spices or their extracts, butylated hydroxyanisole (BHA), butylated hydroxytoluene (BHT)) antioxidants, fat nature and storage conditions $[3,19,20]$.

The mechanism of the antioxidant action consists in their more active interaction with free radicals and air oxygen, due to which radicals are removed from the sphere of the reaction and the chain is broken, thereby, interrupting the autoxidation reaction.

An effect of natural antioxidants, the biologically active complex of the green tea extract, on the acid value under different storage conditions is shown in Figure 7, Figure 8, Figure 9, Figure 10, Figure 11.

It is agreed that a product with the acid value of more than $3.5 \mathrm{mg} \mathrm{KOH} / \mathrm{g}$ is not storable. As can be seen from the graphs, none of the samples exceeded the maximum allowable level during 30 days. This suggests the effectiveness of using the biologically active complex of antioxidants of the green tea extract in production of fats for food purposes instead of synthetic BHA and BHT.

Then, we examined an effect of the biologically active complex of antioxidants of the green tea extract on the peroxide value (Figure 12, Figure 13, Figure 14).

Analysis of the graphs (Figure 12, Figure 13, Figure 14) shows that addition of antioxidants of the green tea extract in an amount of $10 \mathrm{~g}$ per $100 \mathrm{~kg}$ fat ensures adequate storage of all fat types under any storage conditions.

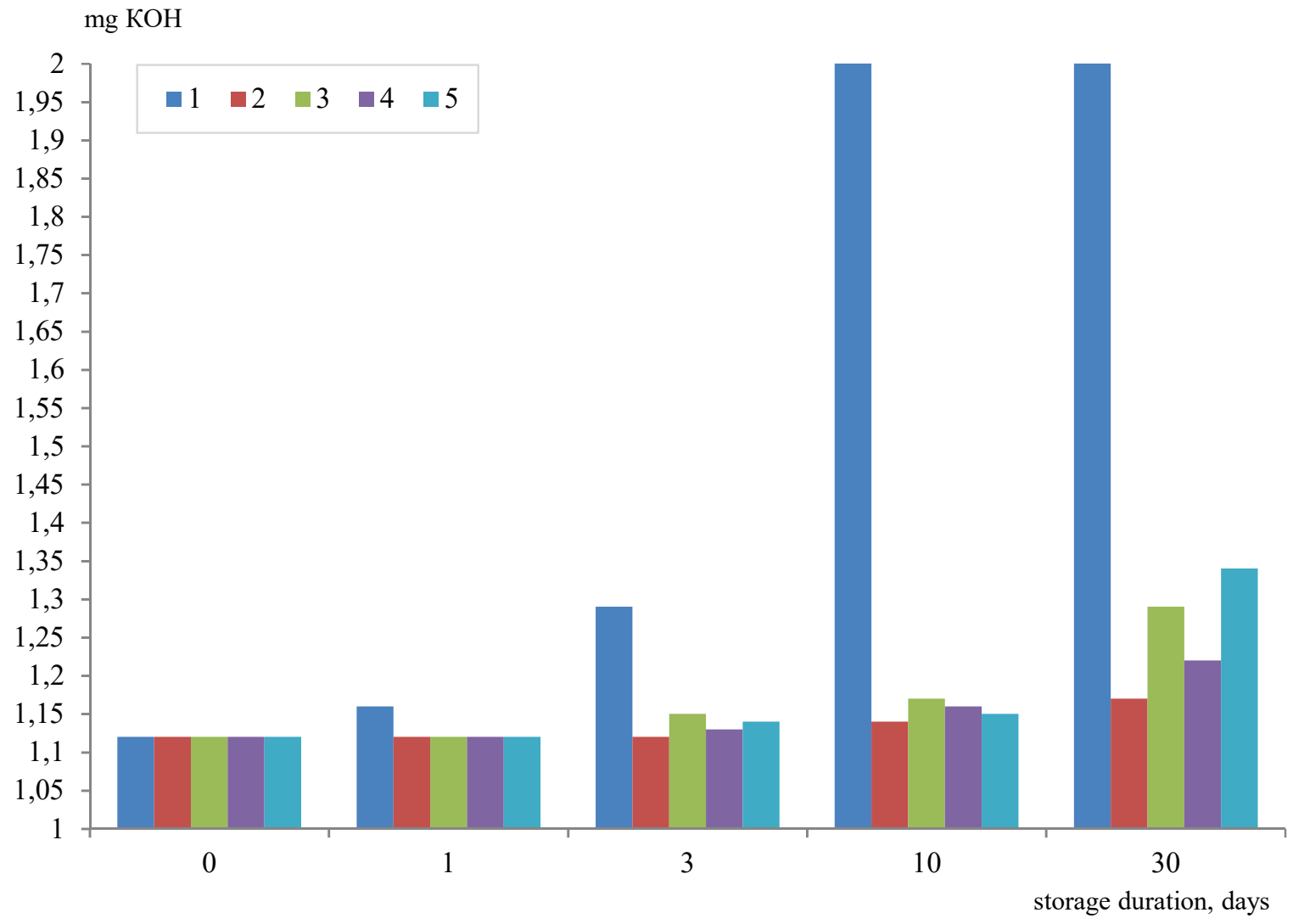

Figure 7. Changes in the acid value in pork backfat under the effect of antioxidants of the green tea extract during storage: 1 - control at $\mathrm{t}=4{ }^{\circ} \mathrm{C} ; 2$ - at $\mathrm{t}=4{ }^{\circ} \mathrm{C} ; 3$ - at $\mathrm{t}=20^{\circ} \mathrm{C}$, under light conditions; 4 - at $\mathrm{t}=20^{\circ} \mathrm{C}$, under dark conditions; 5 - at $\mathrm{t}=20^{\circ} \mathrm{C}$, under conditions of increased humidity 


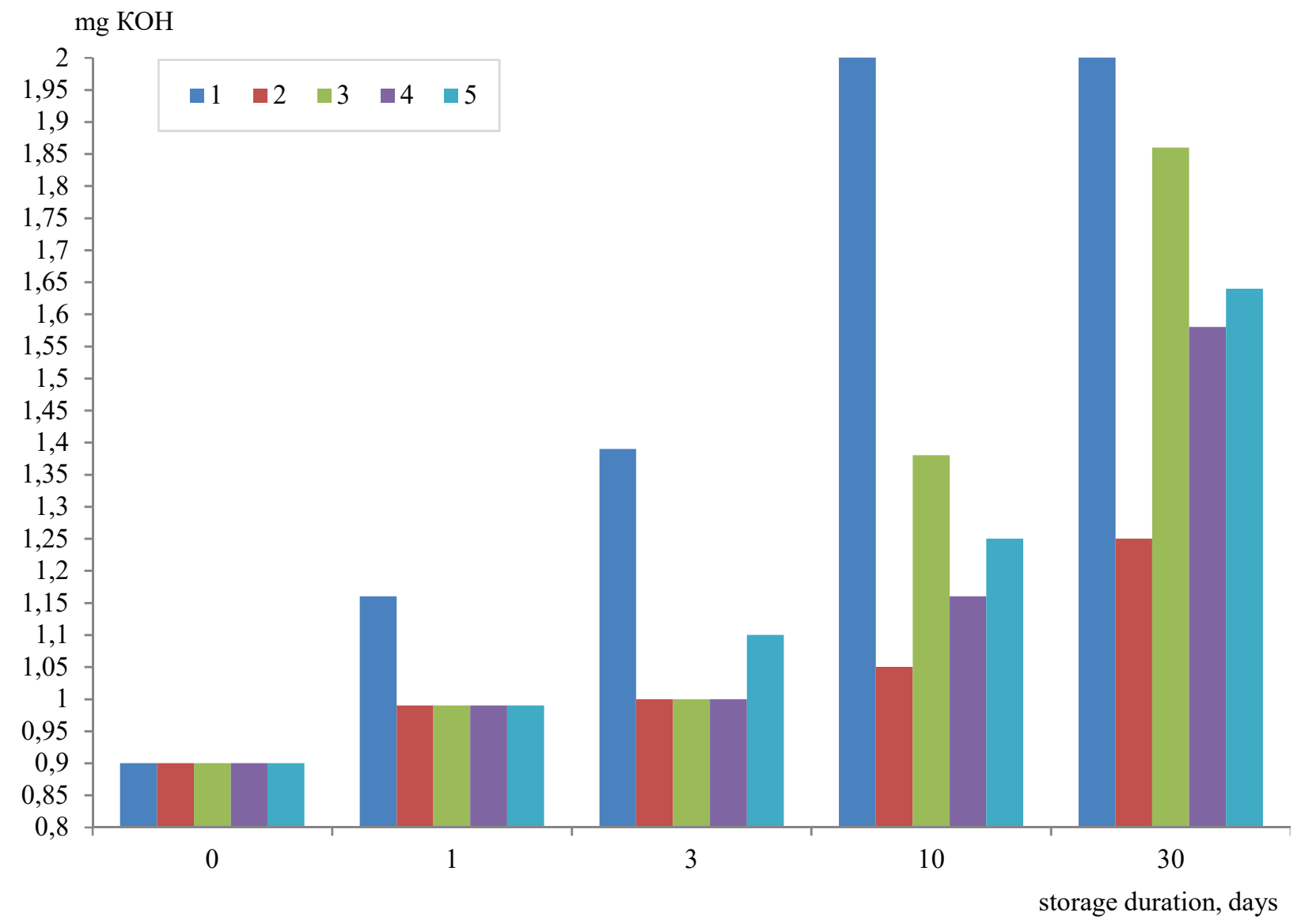

Figure 8. Changes in the acid value in pork fat from flank under the effect of antioxidants of the green tea extract during storage: $1-$ control at $\mathrm{t}=4{ }^{\circ} \mathrm{C} ; 2-$ at $\mathrm{t}=4{ }^{\circ} \mathrm{C} ; 3$ - at $\mathrm{t}=20^{\circ} \mathrm{C}$, under light conditions; 4 - at $\mathrm{t}=20^{\circ} \mathrm{C}$, under dark conditions; 5 - at $\mathrm{t}=20^{\circ} \mathrm{C}$, under conditions of increased humidity

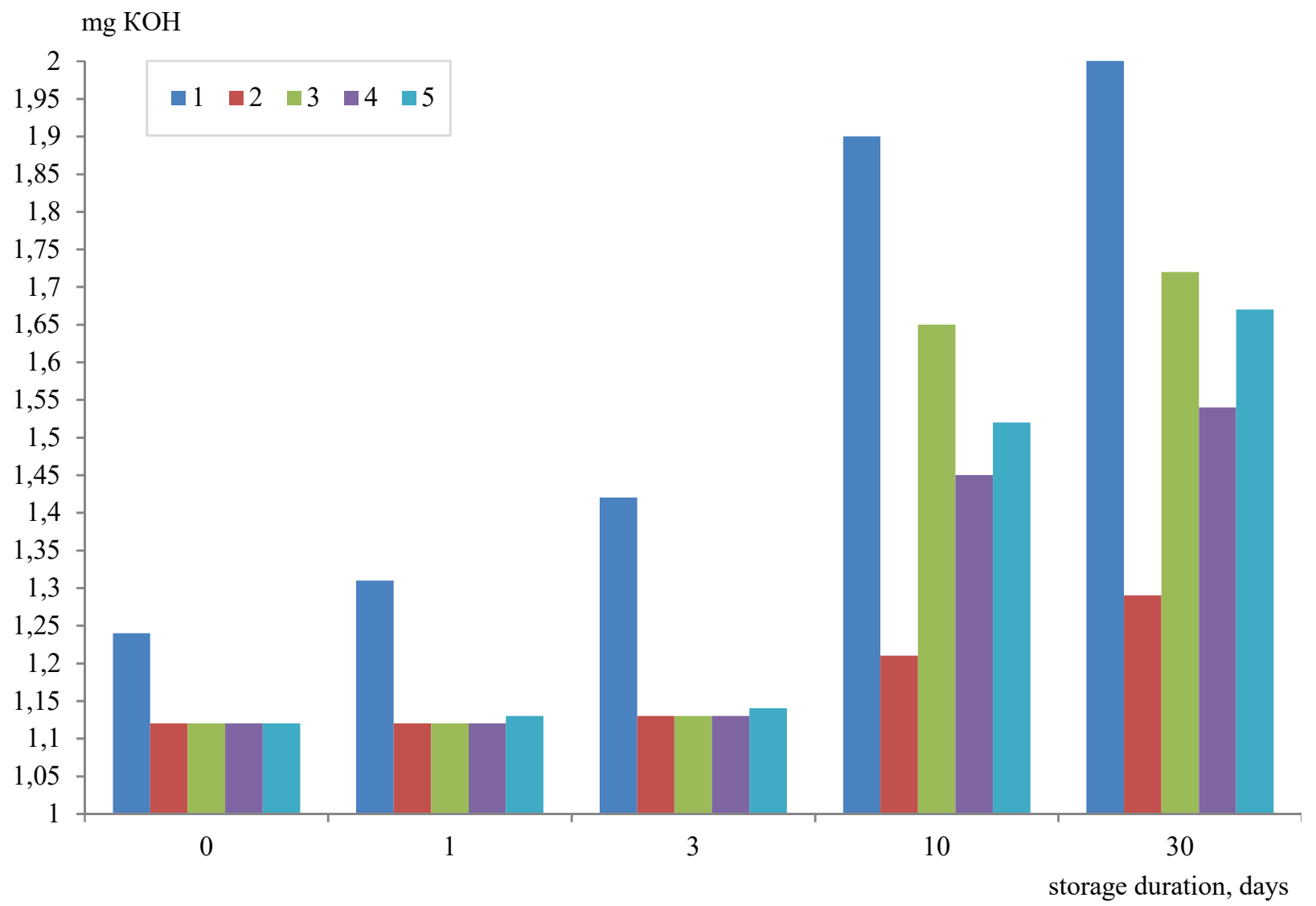

Figure 9. Changes in the acid value in mutton fat under the effect of antioxidants of the green tea extract during storage: $1-$ control at $\mathrm{t}=4{ }^{\circ} \mathrm{C} ; 2-$ at $\mathrm{t}=4{ }^{\circ} \mathrm{C} ; 3-$ at $\mathrm{t}=20^{\circ} \mathrm{C}$, under light conditions; $4-$ at $\mathrm{t}=20^{\circ} \mathrm{C}$, under dark conditions; $5-$ at $\mathrm{t}=20^{\circ} \mathrm{C}$, under conditions of increased humidity 
mg KOH

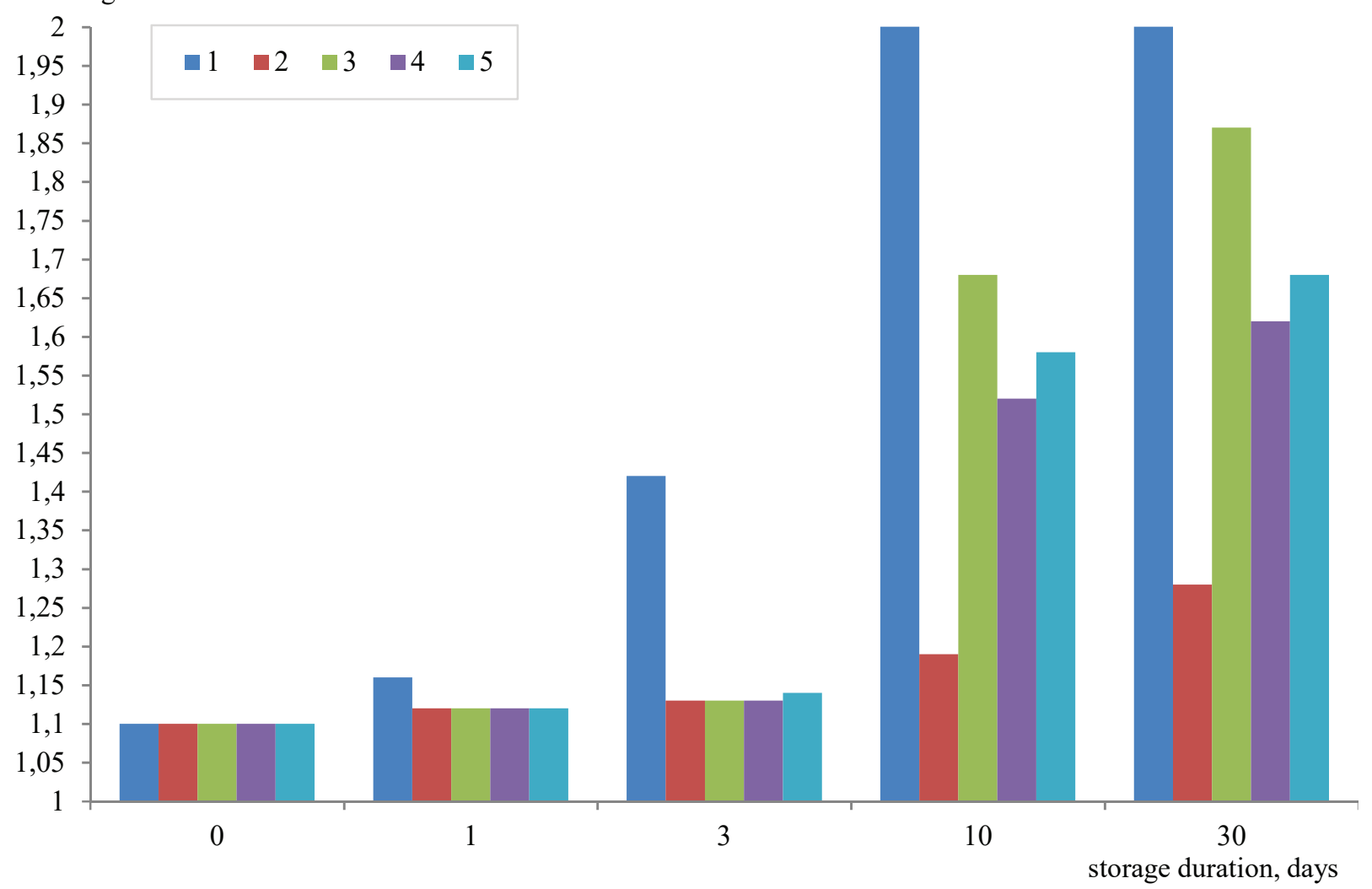

Figure 10. Changes in the acid value in goose fat under the effect of antioxidants of the green tea extract during storage: $1-\operatorname{control}$ at $\mathrm{t}=4^{\circ} \mathrm{C}$; 2 - at $\mathrm{t}=4^{\circ} \mathrm{C} ; 3$ - at $\mathrm{t}=20^{\circ} \mathrm{C}$, under light conditions; 4 - at $\mathrm{t}=20^{\circ} \mathrm{C}$, under dark conditions; 5 - at $\mathrm{t}=20^{\circ} \mathrm{C}$, under conditions of increased humidity

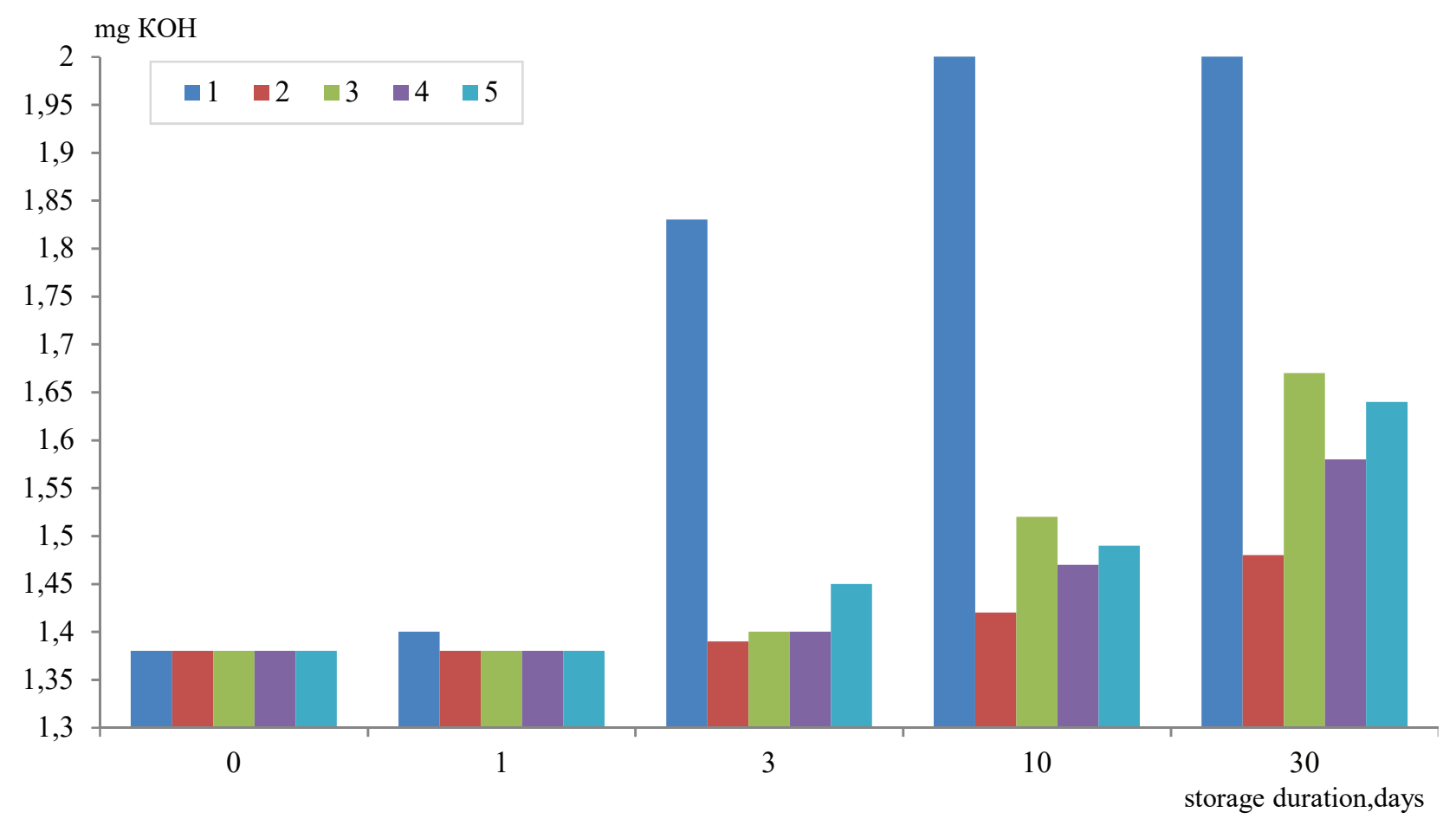

Figure 11. Changes in the acid value in beef fat under the effect of antioxidants of the green tea extract during storage: $1-\operatorname{control}$ at $\mathrm{t}=4^{\circ} \mathrm{C}$; 2 - at $\mathrm{t}=4^{\circ} \mathrm{C} ; 3$ - at $\mathrm{t}=20^{\circ} \mathrm{C}$, under light conditions; 4 - at $\mathrm{t}=20^{\circ} \mathrm{C}$, under dark conditions; 5 - at $\mathrm{t}=20^{\circ} \mathrm{C}$, under conditions of increased humidity 


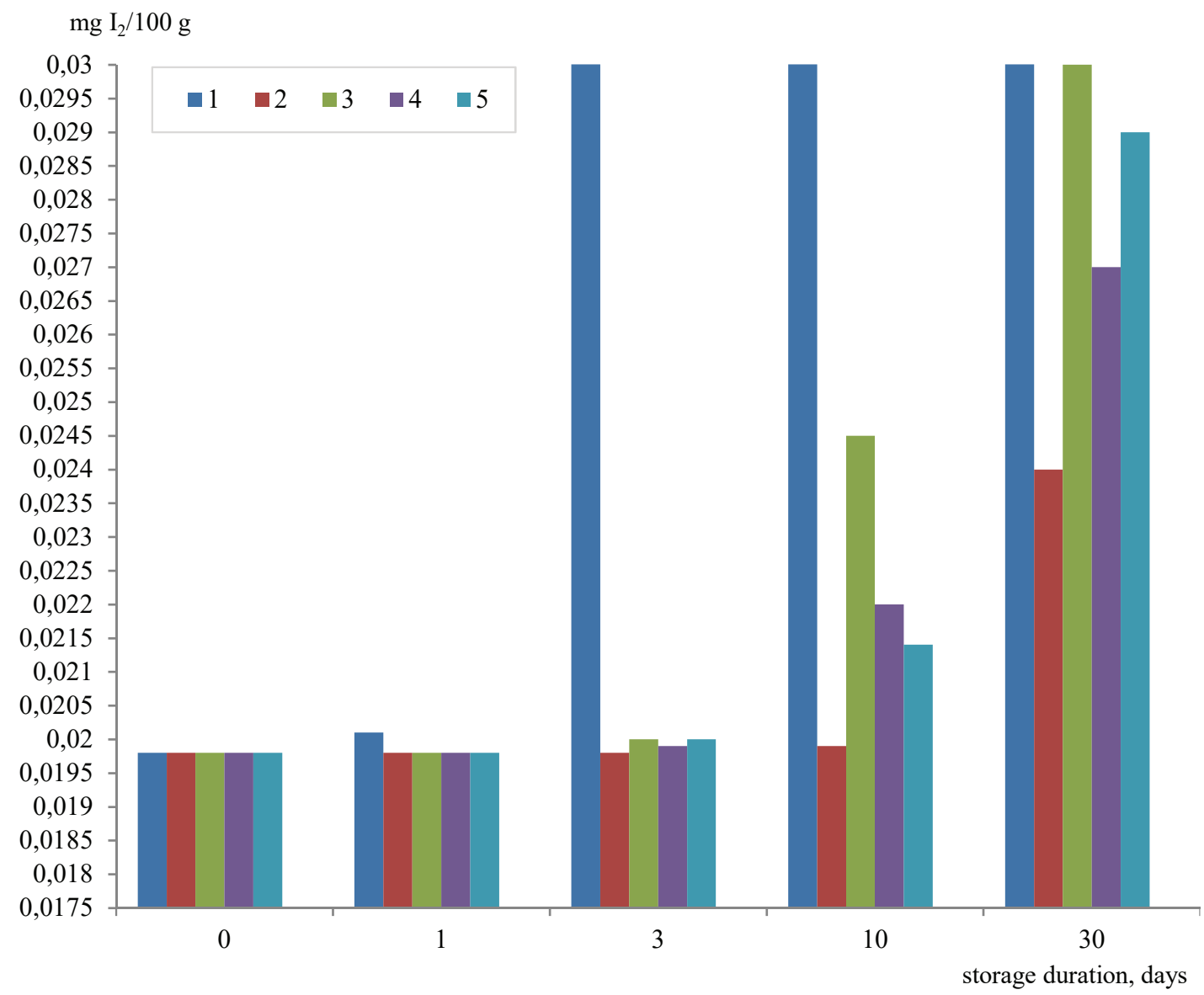

Figure 12. Changes in the peroxide value in pork backfat under the effect of antioxidants of the green tea extract during storage: $1-$ control at $\mathrm{t}=4{ }^{\circ} \mathrm{C} ; 2-$ at $\mathrm{t}=4{ }^{\circ} \mathrm{C} ; 3$ - at $\mathrm{t}=20^{\circ} \mathrm{C}$, under light conditions; $4-$ at $\mathrm{t}=20^{\circ} \mathrm{C}$, under dark conditions; 5 - at $\mathrm{t}=20^{\circ} \mathrm{C}$, under conditions of increased humidity

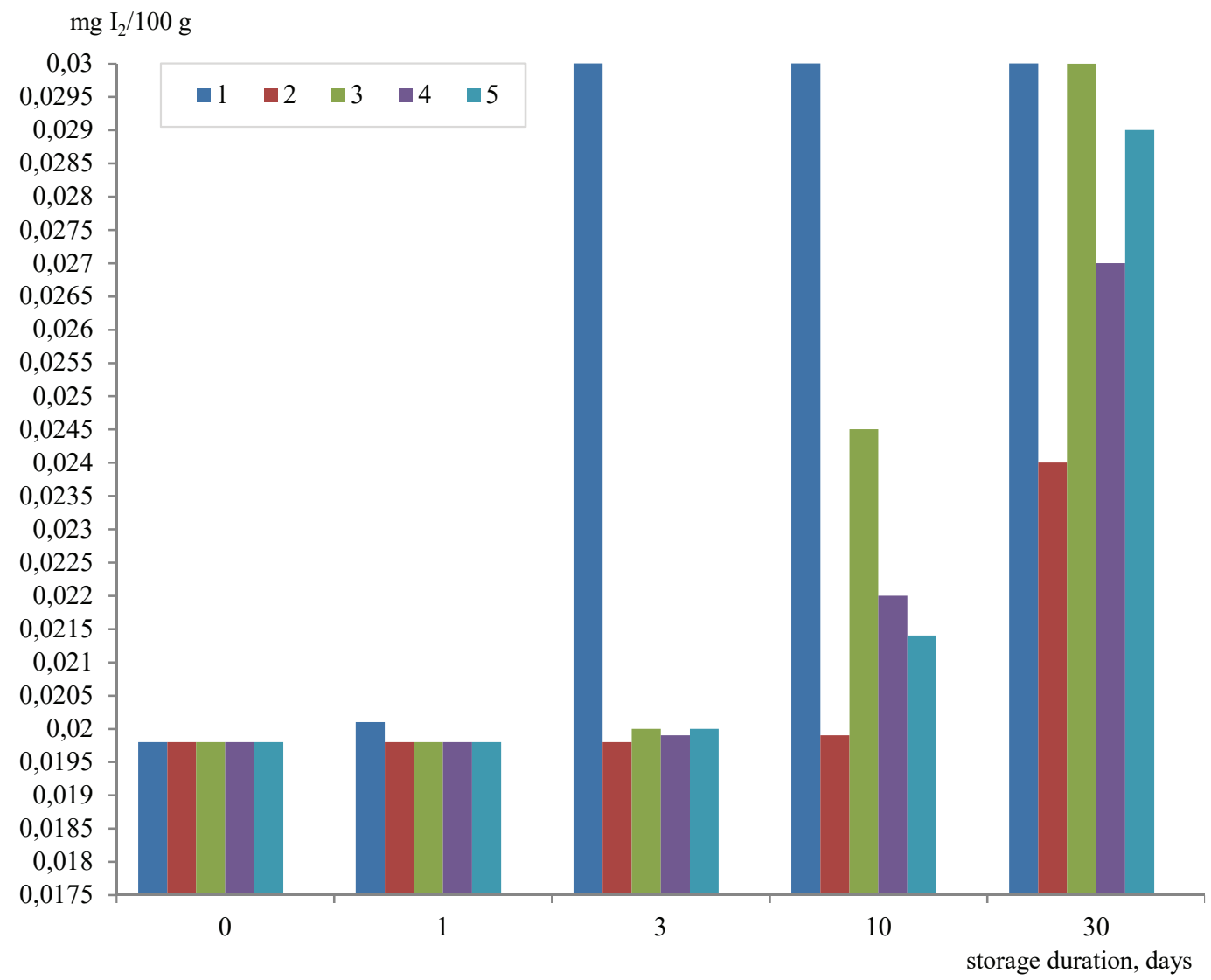

Figure 13. Changes in the peroxide value in pork fat from flank under the effect of antioxidants of the green tea extract during storage: $1-$ control at $\mathrm{t}=4{ }^{\circ} \mathrm{C} ; 2$ - at $\mathrm{t}=4{ }^{\circ} \mathrm{C} ; 3$ - at $\mathrm{t}=20^{\circ} \mathrm{C}$, under light conditions; 4 - at $\mathrm{t}=20^{\circ} \mathrm{C}$, under dark conditions; 5 - at $\mathrm{t}=20^{\circ} \mathrm{C}$, under conditions of increased humidity 


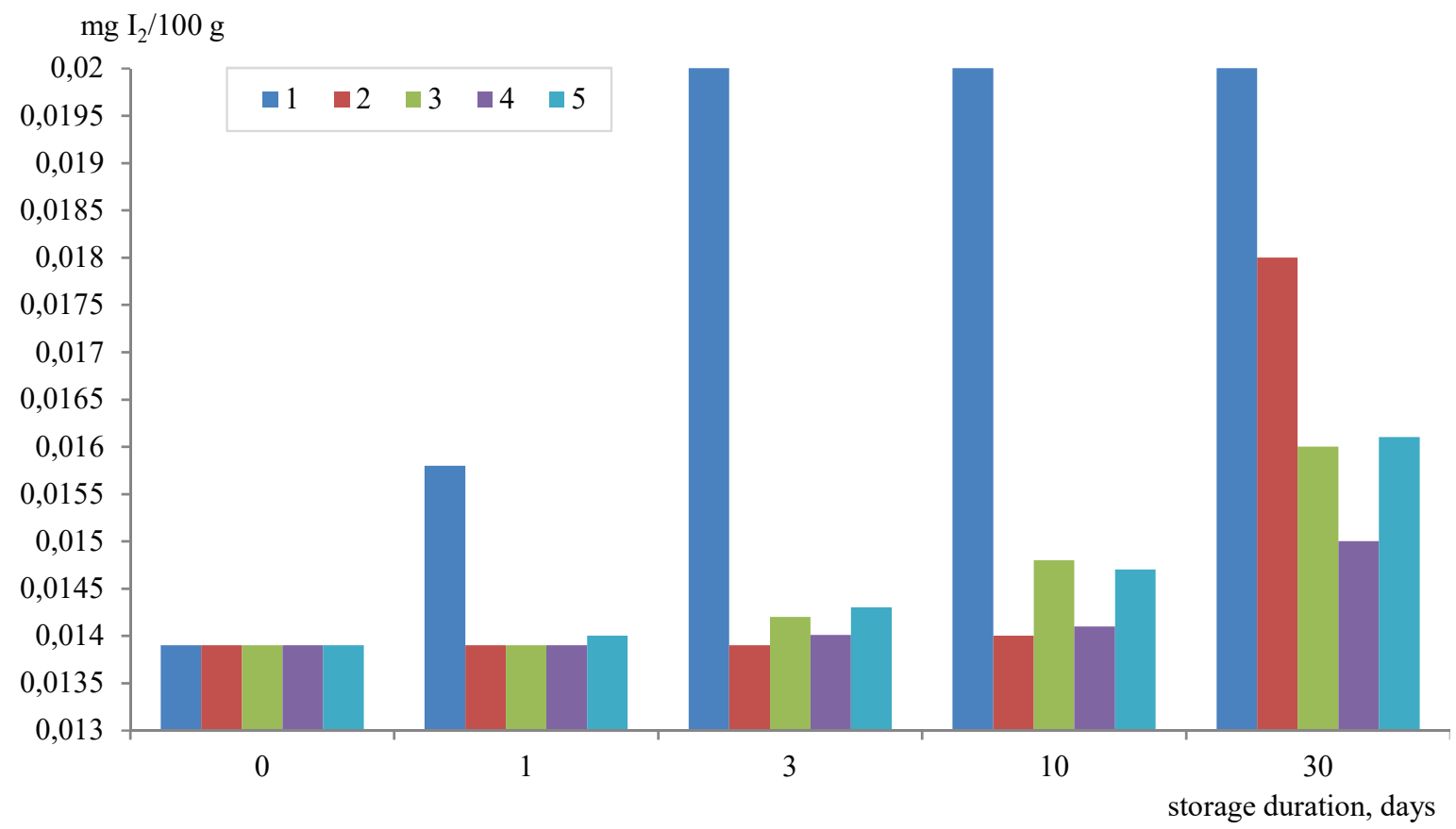

Figure 14. Changes in the peroxide value of mutton fat under the effect of antioxidants of the green tea extract during storage: $1-$ control at $\mathrm{t}=4{ }^{\circ} \mathrm{C} ; 2-$ at $\mathrm{t}=4{ }^{\circ} \mathrm{C} ; 3$ - at $\mathrm{t}=20^{\circ} \mathrm{C}$, under light conditions; 4 - at $\mathrm{t}=20{ }^{\circ} \mathrm{C}$, under dark conditions; $5-$ at $\mathrm{t}=20^{\circ} \mathrm{C}$, under conditions of increased humidity

\section{Conclusion}

Analysis of data on the oxidative spoilage indices allowed us to establish that bioflavonoids of the biologically active complex of the green tea extract possessed the antioxidant activity to the full extent, which makes it possible to recommend them for using as additives with the antioxidant action in fat production.

Organoleptic investigations of the fat samples showed that signs of spoilage (slime formation, rancid odor, color changes, darkening and appearance of the greyish tint) were not observed in any sample with addition of flavonoids of the green tea extract during one month of storage.

Therefore, the performed research showed that addition of bioflavonoids of the green tea extract as antioxidants in an amount of $0.01 \%$ of fat weight allowed achieving the similar effect as addition of $0.02 \%$ BHT. With that, the use of bioflavonoids of the green tea extract did not have a negative effect on fat properties and the human body upon direct consumption.

\section{REFERENCES}

1. Butenko, M. N. (2013). The method for determining the content of dietary proteins, fats and carbohydrates. Agrarian Bulletin of the Urals, 5(111), 9-11. (In Russian)

2. Bogatko, N. M. (2019). Criteria for safety and quality assessment of meat from slaughter animals upon informative indices of animal fat freshness. Current problems of intensive development of animal husbandry, 22-2, 132-139. (In Russian)

3. Zabalueva, Yu. Yu., Bazhenova, B. A., Burkhanova, A. G., Andreeva, S. V. (2019). The effect of rosehip extract on indicators of animal fat oxidation process during storage. ESSUTM Bulletin, 4(75), 46-53. (In Russian)

4. Grigorov, Yu. G., Kozlovskaya, S. G., Medovar, B. Ya. (2014). The role of peculiarities of nutrition in the problem of longevity: longevity. Medical and social aspects. Kiev: Dumka. - 120 p. (In Russian)

5. Ivkova, I. A., Pilyaeva, A. S. (2013). The impact of vegetable fats to increase the shelf life of food products. Bulletin of Omsk State Agricultural University, 2(10), 57-59. (In Russian)

6. Kalashnikova, L. I., Nadykta, V. D. (2014). Effect of heating on the aiological properties of food fats. News of Institutes of Higher Education. Food Technology, 4(430), 31-34. (In Russian)

7. Levachev, M. M., Garbuzov, A. G., Ivaschenko, N. V. (2016). Development of research in the field of the assessment of the biological action of the fatty part of diets. Collection of scientific papers "Theoretical and clinical aspects of nutrition science", 7 , 192-194. (In Russian)

8. Leschukov, K. A., Fedorin, I. Yu. (2014). The method for increasing quality and stability of animal fats during storage. Biology in Agriculture, 4, 5-9. (In Russian)
9. Kalashnikova, L. I., Nazarko, M. D., Lobanov V. G. (2013). Chemical aspects of thermal destruction of fatty acids in frying product. News of Institutes of Higher Education. Food Technology, 5-6(335-336), 8-10. (In Russian)

10. Kireeva, A.V. (2018). Organization of storage and control of stock and raw materials. Bryansk: Bryansk State Agrarian University. - 125 p. (In Russian)

11. Kastornykh, M. S., Kuzmina, V. A., Puchkova, Yu. S. (2014). Commodity research and expertise of edible fats, milk and dairy products. Moscow: Dashkov and K. - 328 p. ISBN978-5-39401592-2 (In Russian)

12. Rudakov, O. B. (2011). Techno-chemical control of fats and fat replacers: teaching guide. St. Petersburg: Lan. - 576 p. (In Russian) 13. Maynikova, N. F., Vasilyev, S. O., Antonov, A. O., Popov, O. N. (2014). The Measuring System of Quality Control of Fats in the Food Industry. Transactions TSTU, 20(2), 261-267. (In Russian) 14. Mishanin, Yu. F. (2017). Biotechnology of rational processing of animal raw materials. St. Petersburg: Lan. - 720 p. ISBN9785-8114-2562-4 (In Russian)

15. Maliuova, V. I. (2014). About using BHT in fat production. Meat Industry, 4, 47-48. (In Russian)

16. Faivishevskiy, M. L., Grebenshikova, T. Yu., Krylova, V. B., Kuregyan, O. D. (2000). Fat emulsions based on plant proteins and new surfactants (Production of minced meat products). Storage and processing of farm products, 6, 29-33. (In Russian) 17. Федорин, И. Ю. Fedorin, I. Yu., Leschukov, К.A. (2014). А method for increasing quality and stability of animal fats during storage. Network scientific journal of the Oryol State Agrarian University, 2(30), 46-50. (In Russian) 
18. Pokrovskiy, A.A. (2014). Biochemical substantiation of the development of products with the increased biological value. Voprosy Pitaniia, 73(1), 23. (In Russian)

19. Rozantsev, E. G. (1992). Health and modern principles of norm setting in rational nutrition. Meat Industry, 3, 8-10. (In Russian)
20. Rogov, I.A., Lipatov, N.N., Aleksashina, V.A. (1984). New trends in the use of non-meat protein ingredients in the technology of combined meat products: Review information. Moscow: TSNIITEI myasomolprom. - 36 p. (In Russian)

\section{AUTHOR INFORMATION}

Konstantin A. Lehukov - doctor of agricultural sciences, professor, Department of food products of animal origin, Orel State agrarian University named after N. V. Parahin, 302019, Orel, Veselaya Sloboda str., 69.

Tel.: +7-920-803-50-40-, E-mail: kostl77@mail.ru

ORCID: https://orcid.org/0000-0002-6200-2568

Sergei S. Tsikin - candidate of technical sciences, senior lecturer, Department of food products of animal origin, Orel State agrarian University named after N. V. Parahin, 302019, Orel, Veselaya Sloboda str., 69.

Tel.: +7-953-814-81-71, E-mail: sergei.tsickin1983@yandex.ru

ORCID: https://orcid.org/0000-0002-1973-4720

* corresponding author

All authors bear responsibility for the work and presented data.

All authors made an equal contribution to the work.

The authors were equally involved in writing the manuscript and bear the equal responsibility for plagiarism.

The authors declare no conflict of interest.

Received 02.03.2020 Accepted in revised 15.03.2020 Accepted for publication 30.03.2020 